\title{
Effects of corticosterone on mild auditory fear conditioning and extinction; role of sex and training paradigm
}

\author{
Sylvie L. Lesuis, Lisa A.E. Catsburg, Paul J. Lucassen, and Harm J. Krugers \\ Brain Plasticity group, Swammerdam Institute for Life Sciences, Center for Neuroscience, University of Amsterdam, \\ 1098 XH Amsterdam, The Netherlands
}

\begin{abstract}
Multiple lines of evidence suggest that glucocorticoid hormones enhance memory consolidation of fearful events. However, most of these studies involve male individuals. Since anxiety, fear, and fear-associated disorders present differently in male and female subjects we investigated in mice whether male and female mice perform differently in a mild, auditory fear conditioning task and tested the modulatory role of glucocorticoid hormones. Using an auditory fear conditioning paradigm with different footshock intensities $(0.1,0.2$, and $0.4 \mathrm{~mA})$ and frequencies $(1 \times$ or $3 \times)$, we find that intraperitoneal injections with corticosterone $(2 \mathrm{mg} / \mathrm{kg})$ immediately after training, altered freezing behavior when repeated footshocks were applied, and that the direction of the effects were opposite in male and female mice. Effects were independent of footshock intensity. In male mice, corticosterone consistently increased freezing behavior in response to the tone, whereas in female mice, corticosterone reduced freezing behavior $24 \mathrm{~h}$ after training. These effects were not related to the phase of the oestrous cycle. In addition, corticosterone enhanced extinction learning for all tones, in both male and female mice. These results emphasize that glucocorticoid hormones influence memory consolidation and retrieval, and underscore sex-specific effects of glucocorticoid hormones in modulating conditioned fear responses.
\end{abstract}

[Supplemental material is available for this article.]

Memories for fearful events are generally retained well (McGaugh and Roozendaal 2002; Roozendaal 2002). Extensive evidence from human and animal studies have associated stress hormones like glucocorticoids (corticosterone in rats; cortisol in humans) with altered memory formation (Roozendaal 2000). Glucocorticoid hormones are produced by the adrenal glands and their release is increased during and after exposure to stress or emotional experiences (Joëls and Baram 2009). These hormones readily cross the blood-brain barrier and bind to mineralocorticoid (MR) and glucocorticoid (GR) receptors present in the brain. Via genomic and nongenomic effects, they can influence neural function and memory formation (Sandi 2011; Joëls et al. 2018). Many studies have reported that corticosterone, as well as synthetic GR agonists, can alter cognitive functions and e.g., enhance memory consolidation (McGaugh and Roozendaal 2002; Roozendaal 2002). While these behavioral effects after short term exposure are usually adaptive in nature, prolonged exposure to elevated glucocorticoid hormones may be deleterious and has been associated with stress-associated disorders (de Kloet et al. 2005).

Many studies on the effects of glucocorticoid hormones have predominantly used male individuals to investigate their effects (Beery and Zucker 2011), while memory formation under the influence of stress, as well as many anxiety, stress, and psychiatric disorders are present with distinct sex differences in humans. For instance, the lifetime prevalence of post-traumatic stress disorder (PTSD) is two times higher in women than in men (Olff 2017). Animal studies have reported striking differences in stressresponsiveness between sexes. For example, female rodents have higher basal corticosterone levels than males (Kitay 1961;

Corresponding author: sylvie.lesuis@gmail.com

Article is online at http://www.learnmem.org/cgi/doi/10.1101/lm.047811.118.
Critchlow et al. 1963; Pollard et al. 1975; Le Mevel et al. 1979; Carey et al. 1995; Figueiredo et al. 2002), and a higher binding capacity for hippocampal GRs (Turner and Weaver 1985). In addition, female rodents express less MRs (Lin et al. 2011) as well as a lower binding of corticosterone to these receptors (Turner 1992, 1997). Interestingly, chronic stress in male rats down-regulates GR immunoreactivity in the dentate gyrus and CA1 region of the hippocampus, but increases GR binding in CA1 in females (Karandrea et al. 2000; Kitraki et al. 2004). In these studies, MR binding was increased in the CA3 region of female, but not in male rats.

Together, these studies suggest sex differences in the action of glucocorticoids. Indeed, sex differences are also present in cognitive performance. Male rodents have been reported to perform better than females in spatial memory tasks like the Morris water maze (e.g., Beiko et al. 2004). Yet, after acute and chronic stress, performance of male rats in spatial memory tasks was impaired (Diamond et al. 1999; Conrad et al. 2003, 2004), whereas female animals improved their spatial memory abilities following stress (Bowman et al. 2001). Sex-differences have also been reported in fear-related memory (Dalla and Shors 2009). However, whether glucocorticoid effects on memory consolidation in auditory fear conditioning paradigm differ between male and female animals, and how different aspects of the training paradigm contribute to these effects, remains largely elusive. We therefore systematically investigated in mice how these hormones regulate fear memory formation in the context of varying training intensities, and whether effects were different between male and female mice.

C 2018 Lesuis et al. This article is distributed exclusively by Cold Spring Harbor Laboratory Press for the first 12 months after the full-issue publication date (see http://learnmem.cshlp.org/site/misc/terms.xhtml). After 12 months, it is available under a Creative Commons License (Attribution-NonCommercial 4.0 International), as described at http://creativecommons.org/licenses/by-nc/4.0/. 


\section{Results}

Effects of shock intensity and frequency on freezing behavior in male and female mice

Male and female mice were trained in an auditory fear conditioning paradigm with varying footshock intensities $(0.1,0.2$, or $0.4 \mathrm{~mA})$ and frequencies $(1 \times$ or $3 \times)$, and freezing behavior to the tone was measured $24 \mathrm{~h}$ later in a novel context by exposing mice to six tones (Fig. 1A). Both the footshock intensity and the frequency of footshocks at training together determined freezing behavior at retrieval (Fig. 1B). Twenty-four hours after training, the three footshock paradigm increased freezing levels relative to a single footshock of the same intensity (frequency effect: $F_{(1,65)}=31.78, P=0.001$ ). Increasing the footshock intensity also increased the freezing levels in response to a tone $24 \mathrm{~h}$ later, also in both sexes (intensity effect: $\left.F_{(2,65)}=40.89, P=0.001\right)$. Female mice overall displayed more freezing behavior than male mice during the retrieval phase (sex effect: $F_{(1,65)}=14.01, P=0.001$; sex $\times$ intensity interaction effect: $F_{(2,65)}=$ $3.31, P=0.05)$. Following a three footshock training paradigm with an intensity of $0.2 \mathrm{~mA}$, female mice displayed increased freezing behavior when compared to males (post hoc: $P<0.05$ ). However, following a three footshock training paradigm with an intensity of $0.4 \mathrm{~mA}$, male and female mice again displayed comparable freezing levels (post hoc: $P>0.05$ ).

\section{Effects of corticosterone treatment on freezing behavior}

To investigate the effects of glucocorticoids, corticosterone or control saline injections were given immediately following the training. Corticosterone significantly affected freezing behavior to the first tone, but differently in male and female mice, and depending on the frequency of the footshock (treatment $\times \operatorname{sex} \times$ frequency:

A

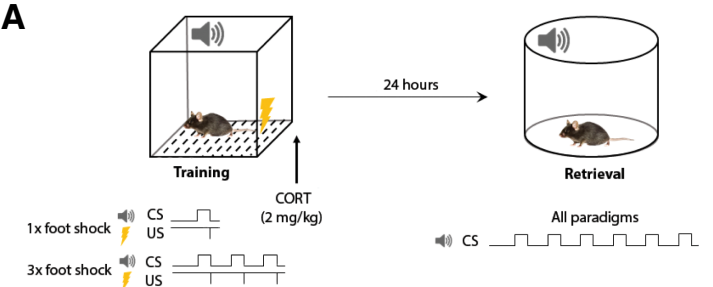

B

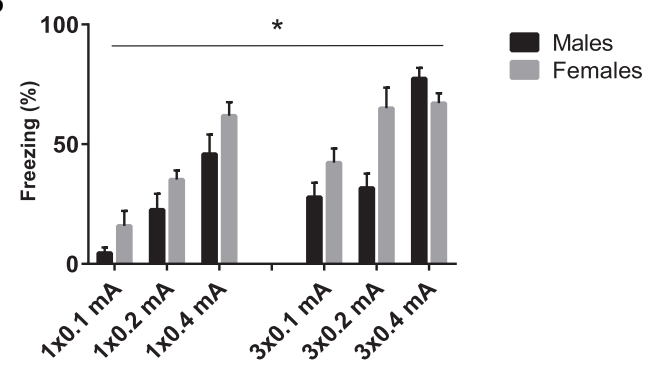

Figure 1. Training and testing paradigm cued fear conditioning. ( $A$ ) Mice are trained in a fear conditioning paradigm with one or three 30 sec tones, coupled with a 2-sec footshock of varying intensity ("training"). Immediately following training, mice were injected i.p. with corticosterone $(2 \mathrm{mg} / \mathrm{kg})$ or saline. Twenty-four hours later, mice were introduced in a novel environment, and reexposed to the same $30 \mathrm{sec}$ tone for six times ("retrieval"). (B) The effects of sex, footshock intensity and footshock frequency on freezing behavior after reexposure to a single tone at retrieval. All mice received a saline injection following training. A main effect was observed for footshock intensity $\left(F_{(2,65)}=40.89, P=0.001\right)$, footshock frequency $\left(F_{(1,65)}=31.78, P=0.001\right)$, and sex $\left(F_{(1,65)}=14.01, P=0.001\right)$, and an interaction effect was found between sex $\times$ intensity $\left(F_{(2,65)}=3.31\right.$, $P=0.05)$, and between sex $\times$ frequency $\times$ intensity $\left(F_{(2,65)}=4.18, P=0.02\right)$.
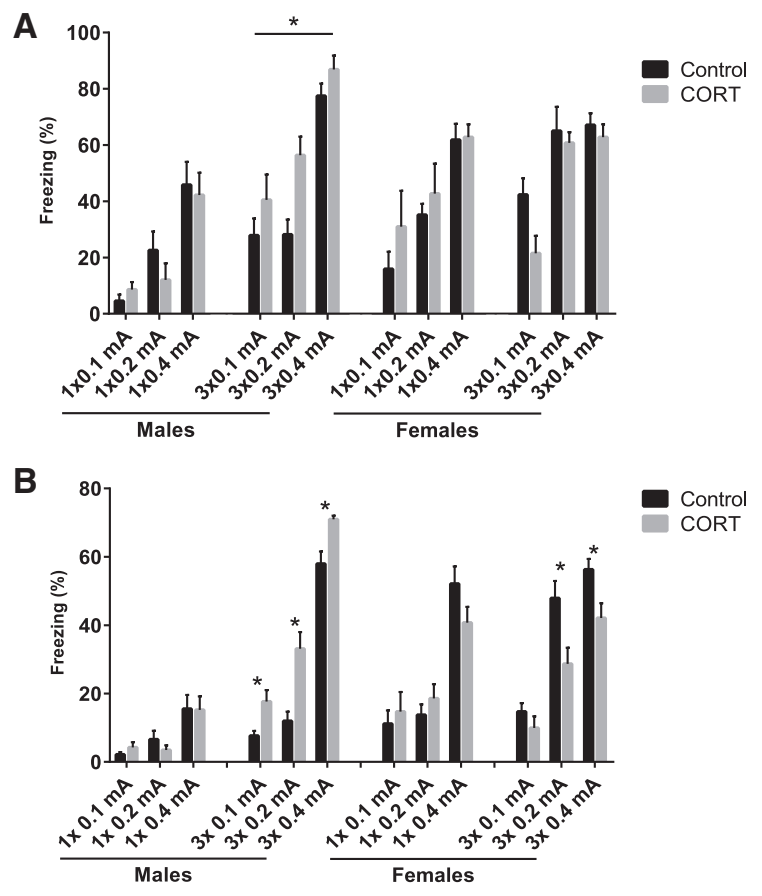

Figure 2. The effect of corticosterone on freezing behavior. (A) Freezing levels to the first tone. A significant interaction effect was observed between sex $\times$ frequency $\times$ treatment $\left(F_{(1,133)}=10.25, P=0.002\right)$, and corticosterone increased freezing only in male mice after a training paradigm with three footshocks $(P=0.049)$. (B) Average freezing behavior over the six tones. Corticosterone resulted in an overall effect on freezing behavior to the tones during retrieval, although differently in male and female mice (sex ${ }^{*}$ treatment effect: $F_{(1,133)}=17.21, P<0.001$ ).

$\left.F_{(1,133)}=10.46, P=0.002\right)$ (Fig. 2A). Post hoc testing only revealed an effect of treatment in male mice following three footshocks $(P=0.049)$.

Corticosterone also significantly affected freezing behavior to the subsequent tones, as measured by the average freezing over the six tones (Fig. 2B; Supplemental Fig. 1; Supplemental Table 1). Corticosterone induced an overall effect on freezing behavior to the tones during retrieval, although differently in male and female mice (sex*treatment effect: $F_{(1,133)}=17.21, P<0.001$ ) (Fig. 2B). These effects were irrespective of frequency or intensity of the training (treatment*frequency: $F_{(1,133)}=0.40, P=0.53$; treatment*intensity: $\left.F_{(1,133)}=0.80, P=0.45\right)$.

\section{Effect of shock frequency (single versus repeated} footshock) on corticosterone effects on freezing behavior After a single footshock, the administration of corticosterone directly after training had no effect on the average freezing levels to the tones during the retrieval, regardless of the footshock intensity or the sex of the animal, as indicated by comparable freezing levels to the tones (treatment effect: $F_{(1,61)}=0.28, P=0.60$ ) (Fig. 2B; Supplemental Fig. 1; Supplemental Table 1). When corticosterone was delivered after three footshocks, it affected freezing at all shock intensities (treatment ${ }^{\star}$ frequency effect: $F_{(5,72)}=7.85, P<$ 0.001 ) (Fig. $2 \mathrm{~B}$ ), except for the $3 \times 0.1 \mathrm{~mA}$ training paradigm, whereas no effect of corticosterone was observed in females (Fig. 2A).

Role of sex in corticosterone-enhanced freezing behavior Interestingly, the effects of corticosterone on memory consolidation were sex-dependent. In male mice, corticosterone "increased" 
freezing to the tones at the $3 \times 0.1 \mathrm{~mA}, 3 \times 0.2 \mathrm{~mA}$, and $3 \times 0.4 \mathrm{~mA}$ training paradigms (Fig. $2 \mathrm{~A}$ ). In female mice, corticosterone "decreased" freezing to the tones after $3 \times 0.2-\mathrm{mA}$, and $3 \times 0.4-\mathrm{mA}$ footshocks, although no effect of corticosterone was observed at the $3 \times$ 0.1-mA footshock paradigm (Fig. 2A).

\section{Effect of oestrous cycle on corticosterone-induced freezing behavior}

No effect of oestrous cycle was observed on freezing behavior, nor on the effects of corticosterone on freezing behavior in female mice (main cycle effect: $F_{(1,46)}=1.13, P=0.29$; treatment ${ }^{*}$ cycle effect: $F_{(1,46)}=0.12, P=0.73$ ) (data not shown).

\section{Effect of corticosterone on extinction learning over the tones}

The extinction of freezing responses after repeated tone-exposures, as measured by the difference in freezing level between tone 1 and tone 6, was different between the sexes. These effects also depended on training frequency and treatment (sex ${ }^{\star}$ frequency ${ }^{*}$ treatment interaction effect: $F_{(1,134)}=4.8, P=0.03$ ) (Fig. 3). In male mice, corticosterone did not affect the extinction following a single footshock. However, following three footshocks, corticosterone increased extinction over the tones in male mice, independent of footshock intensity. In female mice, an effect of corticosterone treatment on extinction was observed following a single footshock, independent of footshock intensity. Following three footshocks, corticosterone treatment no longer affected extinction levels.

\section{Discussion}

In this study we investigated whether male and female mice perform differently in a mild, auditory fear conditioning task with different footshock intensities $(0.1,0.2,0.4 \mathrm{~mA})$ and frequencies (one or three times) and tested the modulatory role of glucocorticoids. We report that corticosterone treatment after training "enhances" freezing behavior at retrieval in male mice, but "reduces" freezing in female mice. The effects of corticosterone treatment were only apparent after a three-times repeated footshock paradigm, and not following a single footshock, regardless of the footshock intensity. Furthermore, corticosterone treatment increased extinction learning over the tones, in both male and female mice.

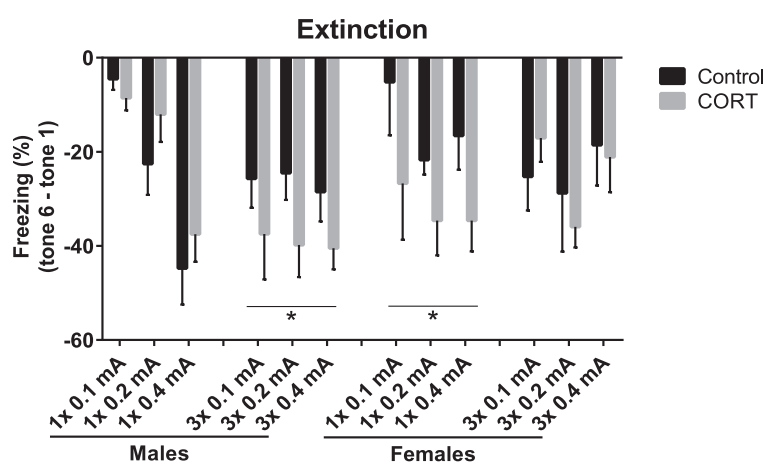

Figure 3. The effects of corticosterone on extinction learning, as measured by the difference in freezing levels between tone 1 and tone 6 at retrieval. There was a significant interaction effect of sex $\times$ frequency $x$ treatment (interaction effect: $\left.F_{(1,134)}=4.8, P=0.03\right)$. *Indicates significant difference between saline and corticosterone-treated mice after a similar training frequency and intensity.

\section{Sex differences}

As expected, subjecting animals to higher footshock intensities resulted in higher freezing levels. Likewise, exposure to three footshocks at training also resulted in higher freezing levels at retrieval than training with a single footshock of the same intensity. This illustrates that freezing behavior at retrieval reflects the intensity of the learning experience at training, which could be an appropriate measure to assess the intensity of the memory, as suggested by previous studies (Sacchetti et al. 1999).

When comparable training parameters were applied, female mice always displayed higher freezing levels than male mice. Only after a three-times repeated footshock of $0.4 \mathrm{~mA}$ did we not observe a difference between male and female mice. This may stem from a ceiling effect, as both sexes displayed relatively high freezing levels. For female mice, the freezing levels did not increase further between a three-times repeated footshock of 0.2 and 0.4 $\mathrm{mA}$, which may be attributed to a ceiling effect as well. For male mice, the increase in freezing between a three-times repeated footshock of 0.2 and $0.4 \mathrm{~mA}$ was still substantial. These findings suggest that fear memory formation and consolidation might be different between the sexes. This could potentially be modulated by female sex hormone-dependent mechanisms (e.g., oestrogen and progesterone), that may influence plasticity-related associative fear memory. Indeed, a similar dimorphic pattern of corticosterone has been reported on a trace-conditioned eye blink response (Shors 2002), and following a contextual training paradigm, females have also been reported to freeze more than males (ter Horst et al. 2012). However, in the current study, we did not observe any effect of oestrous cycle on freezing levels. Studies on sex differences following fear conditioning have been inconsistent, with studies reporting no effects of oestrous cycle on freezing behavior (Cossio et al. 2016), or decreased freezing levels in females (Maren et al. 1994; Pryce et al. 1999; Gupta et al. 2001; Jasnow et al. 2006; Chang et al. 2009; Barha et al. 2010; Kashefi and Rashidy-Pour 2014). Although our study cannot explain the discrepancies between these studies, we speculate that they may arise from experimental variations within the fear-conditioning paradigm animal species or strain.

\section{Corticosterone and freezing behavior}

Numerous studies have illustrated that glucocorticoids facilitate memory consolidation (e.g., Pugh et al. 1997a; Sandi and Rose 1997; Roozendaal 2000, 2002; de Quervain et al. 2009; Xiong et al. 2015). Also in the current study, we find that corticosterone increases memory consolidation. The use of post-training administration of corticosterone, as opposed to corticosterone administration prior to training, suggests an effect on memory consolidation that is not confounded by possible effects on attentional, motivational, or sensory-perceptual mechanisms, that may have occurred when corticosterone treatment would have been given at the time of conditioning or testing. In both male and female mice, and regardless of footshock intensity, corticosterone administration after training did not affect freezing levels at retrieval following a single footshock. Yet, after three repeated footshocks, corticosterone significantly increased freezing behavior during retrieval. An exception was freezing behavior in female mice after a three-times repeated footshock of $0.1 \mathrm{~mA}$. This effect can possibly be attributed to a floor effect, as freezing levels in control female mice were already very low. The difference between a single versus a repeated training paradigm is not merely due to the fact that a repeated footshock induced overall higher freezing levels. For instance, freezing levels in females after a single 0.4-mA footshock are higher than after $3 \times 0.2-\mathrm{mA}$ footshock. Yet, corticosterone resulted in differences when the three-times repeated training paradigm is used. These results suggest that it is not the severity/adversity of the training 
paradigm per se that determines whether corticosterone alters freezing, but that it is the frequency with which the mouse is repeatedly exposed to the tone-footshock that determines the effects of the hormone. Possibly, the learning component in a repeated footshock paradigm is stronger than in a single footshock paradigm, and such a paradigm may therefore be more susceptible to modulation by corticosterone. This notion is supported by the observation by Hui et al. (2004), showing that corticosterone did not enhance freezing behavior following an unpaired presentation of the tone and footshock, or the tone or the shock alone, indicating that a learning process is critical for corticosterone to have an effect.

\section{Effect of sex on corticosterone-induced freezing behavior}

Interestingly, the effects of corticosterone on freezing behavior were opposite in male and female mice. In agreement with previous literature, showing that corticosterone selectively enhances memory in male rats (Sandi and Rose 1994; Cordero and Sandi 1998; Hui et al. 2004), we found that corticosterone enhanced freezing behavior in male mice. These results are consistent with previous findings indicating that corticosterone, as well as drugs that selectively activate GRs, enhance memory consolidation for several types of training, including discrimination learning, inhibitory avoidance, contextual fear conditioning, water-maze spatial training, and appetitive conditioning (Kovács et al. 1977; Flood et al. 1978; Micheau et al. 1984; Roozendaal and McGaugh 1996; Pugh et al. 1997a,b; Sandi and Rose 1997; Cordero and Sandi 1998; Roozendaal et al. 1999). On the other hand, we found that post-training treatment with corticosterone reduced auditory freezing in female mice, providing evidence that also the glucocorticoid effects on memory in these paradigms are sex-dependent.

In agreement with these findings, previous studies have demonstrated that in females, corticosterone also impairs memory formation in a contextual fear conditioning paradigm and in spatial memory tasks (Snihur et al. 2008; ter Horst et al. 2013). These differences may arise from interactions between HPA axis signaling and female sex-hormone dependent pathways (e.g., oestrogen and/or progesterone signaling). Alternatively, the effects of corticosterone have been reported to follow a Yerkes-Dodson or inverted-U shape dose response relationship, in which optimal enhancing effects on memory are seen at midrange doses, whereas high doses are less effective or may even impair memory (Sandi 2011). As female mice have both higher basal corticosterone levels and a stronger corticosterone release upon a stressor (Shors et al. $2001)$, the currently used dose of corticosterone $(2 \mathrm{mg} / \mathrm{kg}$ ) may not have been effective in enhancing memory in females.

Interestingly, the use of oral contraceptives has been shown to affect HPA axis responsiveness during stress exposure in females, resulting in a blunted cortisol response and a lack of stress-induced effects on memory (Cornelisse et al. 2011; Mordecai et al. 2017). Aside from sex-specific differences in stress sensitivity or responsivity (Loi et al. 2017), in the human population, the effects of stress-induced glucocorticoid release on memory may therefore differ between men and women in part because of the high use of oral contraceptives by females. In future studies, the use of oral contraceptives will be important to take into consideration for proper interpretation of the results.

\section{Corticosterone enhances extinction learning over the tones} Previous research has shown that corticosterone facilitates the extinction process (Aerni et al. 2004; Soravia et al. 2006; de Quervain et al. 2009). Our present study shows that corticosterone treatment immediately after training enhanced the extinction of freezing over the tones $24 \mathrm{~h}$ later, when differences in corticosterone levels have already ceased to exist between the groups. The training par- adigm and sex also played a role in this extinction, as in male mice, only a three-times repeated footshock paradigm resulted in enhanced extinction, whereas in females a single footshock paradigm enhanced extinction, irrespective of footshock intensity. The current study cannot clarify the nature of this interaction between sex and footshock frequency. However, both in male and female mice, corticosterone treatment after training enhanced extinction learning, in a comparable way in both sexes. The stronger extinction following corticosterone treatment corresponds to other studies showing facilitated extinction of fear behavior after corticosterone treatment in fear conditioning (Bohus 1970; Bohus et al. 1970; Cai et al. 2006) or appetitive operant conditioning tasks (Micheau et al. 1982).

Interestingly, the corticosterone-induced effects on memory strength (enhancing memory in males while impairing it in females) appear to differ from the effects on extinction, as in both male and female mice, corticosterone enhanced extinction learning. This may indicate the involvement of different brain areas in the effects of corticosterone. Numerous studies have shown that auditory fear conditioning is largely dependent on amygdala activation, whereas prefrontal cortex-amygdala circuits are essential for fear extinction learning (Quirk et al. 2000; Santini et al. 2004). This suggests that corticosterone may have different effects in amygdala and/or prefrontal cortex in male and female mice, which could contribute to the divergent nature of the hormone effect on memory consolidation and extinction.

\section{Conclusion}

The results reported here add to existing evidence that corticosteroid hormones influence memory consolidation. These findings emphasize sex-specific effects of corticosterone in a mild auditory fear condition paradigm. Furthermore, corticosterone enhanced extinction of fearful memories to the same extent in male and female mice. Together, these data suggest that fear memories may be better retained in male animals when compared to female animals. They further emphasize the importance of studying both males and females in stress-related phenotypes and warrant more studies into the mechanisms that underlie sex differences.

\section{Materials and Methods}

\section{Mice and breeding}

All mice were kept under standard housing conditions (temperature $20^{\circ} \mathrm{C}-22^{\circ} \mathrm{C}, 40 \%-60 \%$ humidity) Standard chow and water were available ad libitum, and mice were housed on a $12 / 12 \mathrm{~h}$ light-dark schedule (lights on at 8 a.m.) and a radio provided background noise (Lesuis et al. 2017). All experimental procedures were conducted under the national law and European Union directive 2010/63/EU on animal experiments, and were approved by the animal welfare committee of the University of Amsterdam. Male and female C57Bl/6 mice were bred in house. After weaning, mice were housed with two to five same sex littermates per cage until the start of experiments.

\section{Fear conditioning}

Three month ( \pm 2 wk) old male and female mice were tested in an auditory fear conditioning paradigm. Two weeks prior to fear conditioning, mice were housed individually. All experimental procedures occurred in the morning between 09.00 a.m. and 11.00 a.m. During testing, the mice were recorded by a camera connected to a computer with Ethovision software (version 6.1, Noldus). Mice were placed in a square chamber with black walls $(\mathrm{W} \times \mathrm{L} \times \mathrm{H}: 30 \times$ $24 \times 26 \mathrm{~cm}$ ) which had a stainless steel grid floor connected to a shock generator (Zhou et al. 2010; Xiong et al. 2015), and which had been cleaned with $1 \%$ acidic acid to create a recognizable odor trace. Mice were allowed to explore the context for $3 \mathrm{~min}$, 
after which once or three times, a 30-sec tone was applied $(2.8 \mathrm{kHz}$, $76 \mathrm{~dB})$, coupled to a 2 -sec footshock $(0.1,0.2$, or $0.4 \mathrm{~mA})$ during the last $2 \mathrm{sec}$ of the tone, with an inter-tone-interval of $60 \mathrm{sec}$ (the "training" phase) (see Fig. 1A). After the last tone-footshock pairing, the mice remained in the chamber for $30 \mathrm{sec}$. Twenty-four hours later, mice were introduced in a novel, circular box (diameter: $35 \mathrm{~cm}$, transparent walls, sawdust floor) cleaned with $25 \%$ $\mathrm{EtOH}$. After $3 \mathrm{~min}$, a 30-sec tone was applied for six times, with an inter-tone-interval of $60 \mathrm{sec}$. Freezing behavior during every trial was scored by an observer blind to the experimental condition, with "freezing" being defined as "no body movements except those related to breathing" (Zhou et al. 2009). Four to 15 mice (seven on average) were used (see Supplemental Table 1 for the number of mice per group).

\section{Corticosterone treatment}

Corticosterone (Sigma; $16 \mathrm{mg} / \mathrm{mL}$ dissolved in $99.9 \% \mathrm{EtOH}$ and diluted $40 \times$ in saline) or vehicle $(2.5 \% \mathrm{EtOH}$ in saline) were injected intraperitoneally, immediately after the training (final dose: $2 \mathrm{mg}$ / $\mathrm{kg}$, injection volume: $5 \mu \mathrm{L} / \mathrm{g}$ body weight).

\section{Oestrous cycle determination}

Twenty microliter of $0.9 \%$ saline was used to elute cells from the female's vagina, which were spread on a glass slide and analyzed directly after sampling by means of a light microscope with a $10 \times$ total magnification. Cycle stage of every female was assessed and classified as "oestrous" or "nonoestrous," as described previously (Goldman et al. 2007). Detection of the oestrous phase was performed after fear conditioning. Seventeen mice were in oestrous, and 53 mice were in nonoestrous.

\section{Statistical analyses}

Data were analyzed using SPSS 22.0 (IBM software). All data are expressed as mean \pm standard error of the mean (S.E.M.). Data were considered statistically significant when $P<0.05$. Outliers were determined using a Grubb's test. To determine the effects of treatment on freezing to the tones (Supplemental Table 1; Supplemental Fig. 1), a two-way repeated measures ANOVA was performed using treatment (vehicle versus CORT) as between-subject factors, and freezing behavior to the different tones as the within-subject factor. A $2 \times 3 \times 2$-way ANOVA was performed to assess the difference between groups accounting for sex, footshock intensity, and footshock frequency. A $2 \times 2 \times 3 \times 2$-way ANOVA was performed to compare differences between groups accounting for treatment, sex, footshock intensity, and footshock frequency.

\section{Acknowledgments}

H.J.K., S.L.L., and P.J.L. are supported by Alzheimer Nederland, ISAO grant no. 12354.

\section{References}

Aerni A, Traber R, Hock C, Roozendaal B, Schelling G, Papassotiropoulos A, Nitsch RM, Schnyder U, de Quervain DJ-F. 2004. Low-dose cortisol for symptoms of posttraumatic stress disorder. Am J Psychiatry 161: 1488-1490.

Barha CK, Dalton GL, Galea LA. 2010. Low doses of $17 \alpha$-estradiol and $17 \beta$-estradiol facilitate, whereas higher doses of estrone and $17 \alpha$ - and $17 \beta$-estradiol impair, contextual fear conditioning in adult female rats. Neuropsychopharmacology 35: 547-559.

Beery AK, Zucker I. 2011. Sex bias in neuroscience and biomedical research. Neurosci Biobehav Rev 35: 565-572.

Beiko J, Lander R, Hampson E, Boon F, Cain DP. 2004. Contribution of sex differences in the acute stress response to sex differences in water maze performance in the rat. Behav Brain Res 151: 239-253.

Bohus B. 1970. The medial thalamus and the opposite effect of corticosteroids and adrenocorticotrophic hormone on avoidance extinction in the rat. Acta Physiol Acad Sci Hung 38: 217-223.

Bohus B, Grubits J, Lissák K. 1970. Influence of cortisone on heart rate during fear extinction in the rat. Acta Physiol Acad Sci Hung 37: 265-272.
Bowman RE, Zrull MC, Luine VN. 2001. Chronic restraint stress enhances radial arm maze performance in female rats. Brain Res 904: 279-289.

Cai W-H, Blundell J, Han J, Greene RW, Powell CM. 2006. Postreactivation glucocorticoids impair recall of established fear memory. J Neurosci 26: 9560-9566.

Carey MP, Deterd CH, de Koning J, Helmerhorst F, de Kloet ER. 1995. The influence of ovarian steroids on hypothalamic-pituitary-adrenal regulation in the female rat. J Endocrinol 144: 311-321.

Chang Y-J, Yang C-H, Liang Y-C, Yeh C-M, Huang C-C, Hsu K-S. 2009. Estrogen modulates sexually dimorphic contextual fear extinction in rats through estrogen receptor $\beta$. Hippocampus 19: 1142-1150.

Conrad CD, Grote KA, Hobbs RJ, Ferayorni A. 2003. Sex differences in spatial and non-spatial Y-maze performance after chronic stress. Neurobiol Learn Mem 79: 32-40.

Conrad CD, Jackson JL, Wieczorek L, Baran SE, Harman JS, Wright RL, Korol DL. 2004. Acute stress impairs spatial memory in male but not female rats: influence of estrous cycle. Pharmacol Biochem Behav 78: 569-579.

Cordero MI, Sandi C. 1998. A role for brain glucocorticoid receptors in contextual fear conditioning: dependence upon training intensity. Brain Res 786: 11-17.

Cornelisse S, van Stegeren AH, Joëls M. 2011. Implications of psychosocial stress on memory formation in a typical male versus female student sample. Psychoneuroendocrinology 36: 569-578.

Cossio R, Carreira MB, Vásquez CE, Britton GB. 2016. Sex differences and estrous cycle effects on foreground contextual fear conditioning. Physiol Behav 163: 305-311.

Critchlow V, Liebelt RA, Bar-Sela M, Mountcastle W, Lipscomb HS. 1963. Sex difference in resting pituitary-adrenal function in the rat. Am J Physiol 205: 807-815.

Dalla C, Shors TJ. 2009. Sex differences in learning processes of classical and operant conditioning. Physiol Behav 97: 229-238.

de Kloet E, Joëls M, Holsboer F. 2005. Stress and the brain: from adaptation to disease. Nat Rev Neurosci 6: 463-475.

de Quervain DJ-F, Aerni A, Schelling G, Roozendaal B. 2009. Glucocorticoids and the regulation of memory in health and disease. Front Neuroendocrinol 30: 358-370.

Diamond DM, Park CR, Heman KL, Rose GM. 1999. Exposing rats to a predator impairs spatial working memory in the radial arm water maze. Hippocampus 9: 542-552.

Figueiredo HF, Dolgas CM, Herman JP. 2002. Stress activation of cortex and hippocampus is modulated by sex and stage of estrus. Endocrinology 143: 2534-2540.

Flood JF, Vidal D, Bennett EL, Orme AE, Vasquez S, Jarvik ME. 1978. Memory facilitating and anti-amnesic effects of corticosteroids. Pharmacol Biochem Behav 8: 81-87.

Goldman JM, Murr AS, Cooper RL. 2007. The rodent estrous cycle: characterization of vaginal cytology and its utility in toxicological studies. Birth Defects Res Part B Dev Reprod Toxicol 80: 84-97.

Gupta RR, Sen S, Diepenhorst LL, Rudick CN, Maren S. 2001. Estrogen modulates sexually dimorphic contextual fear conditioning and hippocampal long-term potentiation (LTP) in rats. Brain Res 888: 356-365.

Hui GK, Figueroa IR, Poytress BS, Roozendaal B, McGaugh JL, Weinberger NM. 2004. Memory enhancement of classical fear conditioning by post-training injections of corticosterone in rats. Neurobiol Learn Mem 81: 67-74.

Jasnow AM, Schulkin J, Pfaff DW. 2006. Estrogen facilitates fear conditioning and increases corticotropin-releasing hormone mRNA expression in the central amygdala in female mice. Horm Behav 49: 197-205.

Joëls M, Baram TZ. 2009. The neuro-symphony of stress. Nat Rev Neurosci 10: 459-466.

Joëls M, Karst H, Sarabdjitsingh RA. 2018. The stressed brain of humans and rodents. Acta Physiol (Oxf) 223: e13066.

Karandrea D, Kittas C, Kitraki E. 2000. Contribution of sex and cellular context in the regulation of brain corticosteroid receptors following restraint stress. Neuroendocrinology 71: 343-353.

Kashefi A, Rashidy-Pour A. 2014. Effects of corticosterone on contextual fear consolidation in intact and ovariectomized female rats. Neurobiol Learn Mem 114: 236-241.

Kitay JI. 1961. Sex differences in adrenal cortical secretion in the rat. Endocrinology 68: 818-824.

Kitraki E, Kremmyda O, Youlatos D, Alexis MN, Kittas C. 2004. Gender-dependent alterations in corticosteroid receptor status and spatial performance following 21 days of restraint stress. Neuroscience 125: $47-55$.

Kovács GL, Telegdy G, Lissák K. 1977. Dose-dependent action of corticosteroids on brain serotonin content and passive avoidance behavior. Horm Behav 8: 155-165. 
Le Mevel JC, Abibol S, Beraud G, Maniey J. 1979. Temporal changes in plasma adrenocorticotropin concentration after repeated neurotropic stress in male and female rats. Endocrinology 105: 812-817.

Lesuis SL, van Hoek BACE, Lucassen PJ, Krugers HJ. 2017. Early postnatal handling reduces hippocampal amyloid plaque formation and enhances cognitive performance in APPswe/PS1dE9 mice at middle age. Neurobiol Learn Mem 144: 27-35.

Lin E-JD, Choi E, Liu X, Martin A, During MJ. 2011. Environmental enrichment exerts sex-specific effects on emotionality in C57BL/6J mice. Behav Brain Res 216: 349-357.

Loi M, Mossink JCL, Meerhoff GF, Den Blaauwen JL, Lucassen PJ, Joëls M. 2017. Effects of early-life stress on cognitive function and hippocampal structure in female rodents. Neuroscience 342: 101-119.

Maren S, De Oca B, Fanselow MS. 1994. Sex differences in hippocampal long-term potentiation (LTP) and Pavlovian fear conditioning in rats: positive correlation between LTP and contextual learning. Brain Res 661: 25-34.

McGaugh JL, Roozendaal B. 2002. Role of adrenal stress hormones in forming lasting memories in the brain. Curr Opin Neurobiol 12: 205-210.

Micheau J, Destrade C, Soumireu-Mourat B. 1982. Posttrial injections of corticosterone in dorsal hippocampus of the BALB/c mouse facilitate extinction of appetitive operant conditioning in the Skinner box]. $C R$ Seances Acad Sci III 294: 1109-1112.

Micheau J, Destrade C, Soumireu-Mourat B. 1984. Time-dependent effects of posttraining intrahippocampal injections of corticosterone on retention of appetitive learning tasks in mice. Eur J Pharmacol 106: 39-46.

Mordecai KL, Rubin LH, Eatough E, Sundermann E, Drogos L, Savarese A, Maki PM. 2017. Cortisol reactivity and emotional memory after psychosocial stress in oral contraceptive users. J Neurosci Res 95: $126-135$.

Olff M. 2017. Sex and gender differences in post-traumatic stress disorder: an update. Eur J Psychotraumatol 8: 1351204

Pollard I, White BM, Bassett JR, Cairncross KD. 1975. Plasma glucocorticoid elevation and desynchronization of the estrous cycle following unpredictable stress in the rat. Behav Biol 14: 103-108.

Pryce CR, Lehmann J, Feldon J. 1999. Effect of sex on fear conditioning is similar for context and discrete CS in Wistar, Lewis and Fischer rat strains. Pharmacol Biochem Behav 64: 753-759.

Pugh CR, Fleshner M, Rudy JW. 1997a. Type II glucocorticoid receptor antagonists impair contextual but not auditory-cue fear conditioning in juvenile rats. Neurobiol Learn Mem 67: 75-79.

Pugh CR, Tremblay D, Fleshner M, Rudy JW. 1997b. A selective role for corticosterone in contextual-fear conditioning. Behav Neurosci 111: 503-511.

Quirk GJ, Russo GK, Barron JL, Lebron K. 2000. The role of ventromedial prefrontal cortex in the recovery of extinguished fear. J Neurosci 20: 6225-6231.

Roozendaal B. 2000. Glucocorticoids and the regulation of memory consolidation. Psychoneuroendocrinology 25: 213-238.

Roozendaal B. 2002. Stress and memory: opposing effects of glucocorticoids on memory consolidation and memory retrieval. Neurobiol Learn Mem 78: $578-595$.

Roozendaal B, McGaugh JL. 1996. Amygdaloid nuclei lesions differentially affect glucocorticoid-induced memory enhancement in an inhibitory avoidance task. Neurobiol Learn Mem 65: 1-8.
Roozendaal B, Nguyen BT, Power AE, McGaugh JL. 1999. Basolateral amygdala noradrenergic influence enables enhancement of memory consolidation induced by hippocampal glucocorticoid receptor activation. Proc Natl Acad Sci 96: 11642-11647.

Sacchetti B, Ambroqi Lorenzini C, Baldi E, Tassoni G, Bucherelli C. 1999. Memorization of contextual and CS conditioned fear response (freezing) in a one-trial acquisition paradigm. Arch Ital Biol 137: 235-248.

Sandi C. 2011. Glucocorticoids act on glutamatergic pathways to affect memory processes. Trends Neurosci 34: 165-176.

Sandi C, Rose S. 1994. Corticosteroid receptor antagonists are amnestic for passive avoidance learning in day-old chicks. Eur J Neurosci 6: 1292-1297.

Sandi C, Rose SP. 1997. Training-dependent biphasic effects of corticosterone in memory formation for a passive avoidance task in chicks. Psychopharmacology (Berl) 133: 152-160.

Santini E, Ge H, Ren K, Peña de Ortiz S, Quirk GJ. 2004. Consolidation of fear extinction requires protein synthesis in the medial prefrontal cortex. $J$ Neurosci 24: 5704-5710.

Shors TJ. 2002. Opposite effects of stressful experience on memory formation in males versus females. Dialogues Clin Neurosci 4: 139-147.

Shors TJ, Miesegaes G, Beylin A, Zhao M, Rydel T, Gould E. 2001. Neurogenesis in the adult is involved in the formation of trace memories. Nature 410: 372-376.

Snihur AWK, Hampson E, Cain DP. 2008. Estradiol and corticosterone independently impair spatial navigation in the Morris water maze in adult female rats. Behav Brain Res 187: 56-66.

Soravia LM, Heinrichs M, Aerni A, Maroni C, Schelling G, Ehlert U, Roozendaal B, de Quervain DJ-F. 2006. Glucocorticoids reduce phobic fear in humans. Proc Natl Acad Sci 103: 5585-5590.

ter Horst JP, van der Mark MH, Arp M, Berger S, de Kloet ER, Oitzl MS. 2012. Stress or no stress: Mineralocorticoid receptors in the forebrain regulate behavioral adaptation. Neurobiol Learn Mem 98: 33-40.

ter Horst JP, Kentrop J, de Kloet ER, Oitzl MS. 2013. Stress and estrous cycle affect strategy but not performance of female C57BL/6J mice. Behav Brain Res 241: 92-95.

Turner BB. 1992. Sex differences in the binding of type I and type II corticosteroid receptors in rat hippocampus. Brain Res 581: 229-236.

Turner BB. 1997. Influence of gonadal steroids on brain corticosteroid receptors: a minireview. Neurochem Res 22: 1375-1385.

Turner BB, Weaver DA. 1985. Sexual dimorphism of glucocorticoid binding in rat brain. Brain Res 343: 16-23.

Xiong H, Casse F, Zhou Y, Zhou M, Xiong Z-Q, Joëls M, Martin S, Krugers HJ. 2015. mTOR is essential for corticosteroid effects on hippocampal AMPA receptor function and fear memory. Learn Mem 22: 577-583.

Zhou M, Conboy L, Sandi C, Joëls M, Krugers HJ. 2009. Fear conditioning enhances spontaneous AMPA receptor-mediated synaptic transmission in mouse hippocampal CA1 area. Eur J Neurosci 30: 1559-1564.

Zhou M, Bakker EHM, Velzing EH, Berger S, Oitzl M, Joëls M, Krugers HJ. 2010. Both mineralocorticoid and glucocorticoid receptors regulate emotional memory in mice. Neurobiol Learn Mem 94: 530-537.

Received May 17, 2018; accepted in revised form July 13, 2018. 


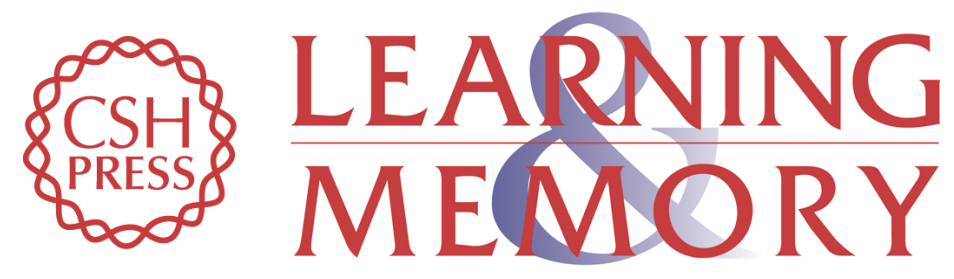

\section{Effects of corticosterone on mild auditory fear conditioning and extinction; role of sex and training paradigm}

Sylvie L. Lesuis, Lisa A.E. Catsburg, Paul J. Lucassen, et al.

Learn. Mem. 2018, 25:

Access the most recent version at doi:10.1101/Im.047811.118

\section{Supplemental http://learnmem.cshlp.org/content/suppl/2018/09/11/25.10.544.DC1 Material}

References This article cites 69 articles, 7 of which can be accessed free at: http://learnmem.cshlp.org/content/25/10/544.full.html\#ref-list-1

Creative This article is distributed exclusively by Cold Spring Harbor Laboratory Press for the Commons first 12 months after the full-issue publication date (see

License http://learnmem.cshlp.org/site/misc/terms.xhtml). After 12 months, it is available under a Creative Commons License (Attribution-NonCommercial 4.0 International), as described at http://creativecommons.org/licenses/by-nc/4.0/.

Email Alerting Receive free email alerts when new articles cite this article - sign up in the box at the Service top right corner of the article or click here. 